\title{
RESPONSE OF TISSUE CULTURED BANANA (Musa acuminate L.) cV. GRAND NAINE TO DIFFERENT LEVELS OF NUTRIENTS UNDER DRIP FERTIGATION AND BLACK PLASTIC MULCH
}

\author{
SANTOSH, D. T. ${ }^{*}-$ TIWARI, K. N. \\ Agricultural and Food Engineering Department, Indian Institute of Technology, \\ Kharagpur, West Bengal, India \\ *Corresponding author \\ e-mail:dtsantosh@gmail.com \\ (Received 27 Jun 2017; accepted $2^{\text {nd }}$ Oct 2017)
}

\begin{abstract}
A field experiment was carried out in two crop seasons in the lateritic sandy loam soils of Kharagpur, West Bengal, India, to investigate the response of banana (Musa acuminata L.) cv. Grand Naine at different levels of nitrogen, phosphorous and potassium nutrients applications through drip fertigation and plastic mulch. A randomized complete block design was used with four fertigation levels in conjunction with mulch and without mulch. Fertigation levels caused a significant increase in fruit yield and determined the response to $\mathrm{N}, \mathrm{P}$ and $\mathrm{K}$ fertilizers. The results of recommended dose of fertilizers application through drip either alone or in conjunction with black plastic mulch conditions were compared with other fertigation treatments in terms of growth and crop of yield. Both the main and ratoon crops performed best for 80 per cent of the recommended fertigation dose (160 N: 48 P: $240 \mathrm{~kg}_{\text {plant }}{ }^{-1}$ year $^{-1}$ ) covered with plastic mulch in respect of (a) growth parameters; maximum plant height, stem girth, functional leaves, yield parameters and shortened total crop duration for 34 days and for (b) quality parameters; higher levels of TSS, reducing sugar and non-reducing sugar, pulp:peel ratio and lower content of acidity. Hence, fertigation with 80 per cent of the recommended dose coupled with plastic mulch was found to be optimum and economical for banana cultivation.
\end{abstract}

Keywords: crop coefficient; nitrogen; potassium; nutrient conversion efficiency; $B$-C ratio

\section{Introduction}

Banana is a fast growing plant that requires high and continuous nutrient and water supplies to sustain a yearlong cycle and ensure economically high yield. These nutrients may be partly supplied by the soil, but fertilizer application is generally needed to satisfy the needs of theplant and to obtain profitable production. In almost all thefertigation studies, researchers suggested high nutrition (nitrogen, phosphorous, potassium) requirement of banana crop (Lahav, 1995). According to Lahav (1995), a banana crop yielding $50 \mathrm{t} \mathrm{ha}^{-1}$ requires about 390 of $\mathrm{N}, 50$ of $\mathrm{P}$ and $1440 \mathrm{of} \mathrm{K}\left(\mathrm{kg} \mathrm{ha}^{-1}\right)$.

The increasing fertilizer costs and the demand have emphasized the need for full exploitation of sources of nutrientson a global scale. So in today's perspective, it is essential, especially in crops like banana which are the heavy feeder of nutrients it is desired to use efficien tmethod of fertilizer application and splitting the dose to get maximum fertilizer use efficiency (FUE) and net profit. Under sub-tropical conditions, soil nutrients will be leached rapidly due to various factors and therefore it should be applied in small doses at shorter intervals. In recent years, liquid fertilizers are used as astrong alternative to solid fertilizers. The major advantage of liquid fertilizers is that, they are completely soluble in water and can be applied through drip system with an ease, without any harm and in number of splits. The second strong point goes in favour of liquid fertilizeris that they contain major essential nutrients in readily available form. In the fertigation process predissolved soluble fertilizers are injected into the feeder line 
of drip irrigation system. Fertigation increases the nutrient use efficiency by $30-40 \%$, prevents soil degradation, reduced the cost of fertilizer application and minimizes the pollution of groundwater, also preventing losses through runoff and leaching. It ultimately increases the FUE by increasing the nutrient uptake and minimizing the losses. It also improves the productivity andquality of the produce (Srinivas, 1999; Mahalakshmi et al., 2001; Pandey et al., 2001).

Mulches also contribute to the crop productivity by way of influencing moisture content, soil productivity, weed control etc. (Sweeney et al. 1987). Use of different types of soil covers ormulches like straw, leaves, husk, crop residues and black plastics have been found to conserve moisture, nutrients, control weeds, moderate soil temperature and increase in yield ofdifferent vegetables. It is observed from studies that beneficial response of plants to mulch includes earlier production (Call and Courter, 1989), greater total yield and reduced insect and disease problems (Greenough et al., 1990). The yield response of plastic mulch in vegetable and fruit crops is reported to be greater than organic mulches (Tiwari et. al., 1998a,b; Tiwari et. al., 2014). The combined effect of fertigation and mulch on banana crop yield has not been studied for sub humid climatic and lateritic soil condition.

The objective of the present study is to investigate the response of different levels of fertigation through drip and black plastic mulch on yield and nutrient use efficiency of banana crop. It is alsoproposed to investigate the effects of cropping on chemical properties of soil.

\section{Materials and Methods}

Experiment was conducted at the Experimental Farm area of Precision Farming Development Centre Project, Agricultural and Food Engineering Department, Indian Institute of Technology, Kharagpur, India. The experimental site is located at flat land with latitude of $22^{\circ} 18.5^{\prime} \mathrm{N}$, longitude of $87^{\circ} 19^{\prime} \mathrm{E}$ and an altitude of $48 \mathrm{~m}$ above mean sea level. The local climate is sub-humid subtropical with an average annual rainfall of $1390 \mathrm{~mm}$, of which about $80 \%$ is received during June to October. The mean monthly minimum temperature is $6{ }^{0} \mathrm{C}$ in January, whereas the mean monthly maximum temperature is $43.5{ }^{\circ} \mathrm{C}$ in May. The mean monthly relative humidity varies from $35 \%$ in February to $96 \%$ during July-August. The soil of the experimental area is lateritic with sandy loam texture.

The experiments were laid out with tissue cultured banana cv. Grand Naine as a test crop in randomized block design (RBD) with eight treatments and three replications (Figure 1a). Each treatment had a net area of $2 \mathrm{~m} \times 15 \mathrm{~m}$ with 15 plants in each treatment. Banana was planted on raised bed and four treatments (12 rows) of crop bed. The bed was covered with black plastic mulch of 50 micron thickness of $1 \mathrm{~m}$ wide and $10 \mathrm{~m}$ long for each row (Figure $1 \mathrm{~b}$ ). The details of the treatments are furnished below.

$\mathrm{T}_{1}(1.2 \mathrm{RDF}+\mathrm{M}): \quad 120 \%$ of fertilizer requirement application through drip and plastic mulch $\mathrm{T}_{2}$ (1.2 RDF): $\quad 120 \%$ of fertilizer requirement application through drip and without mulch $\mathrm{T}_{3}(\mathrm{RDF}+\mathrm{M}): \quad 100 \%$ of fertilizer requirement application through drip and plastic mulch $\mathrm{T}_{4}$ (RDF): $\quad 100 \%$ of fertilizer requirement application through drip and without mulch $\mathrm{T}_{5}(0.8 \mathrm{RDF}+\mathrm{M}): \quad 80 \%$ of fertilizer requirement application through drip and plastic mulch T6 $6.8 \mathrm{RDF}): \quad 80 \%$ of fertilizer requirement application through drip and without mulch $\mathrm{T} 7(0.6 \mathrm{RDF}+\mathrm{M}): \quad 60 \%$ of fertilizer requirement application through drip and plastic mulch $\mathrm{T}_{8}(0.6 \mathrm{RDF})$ : $60 \%$ of fertilizer requirement application through drip and without mulch 


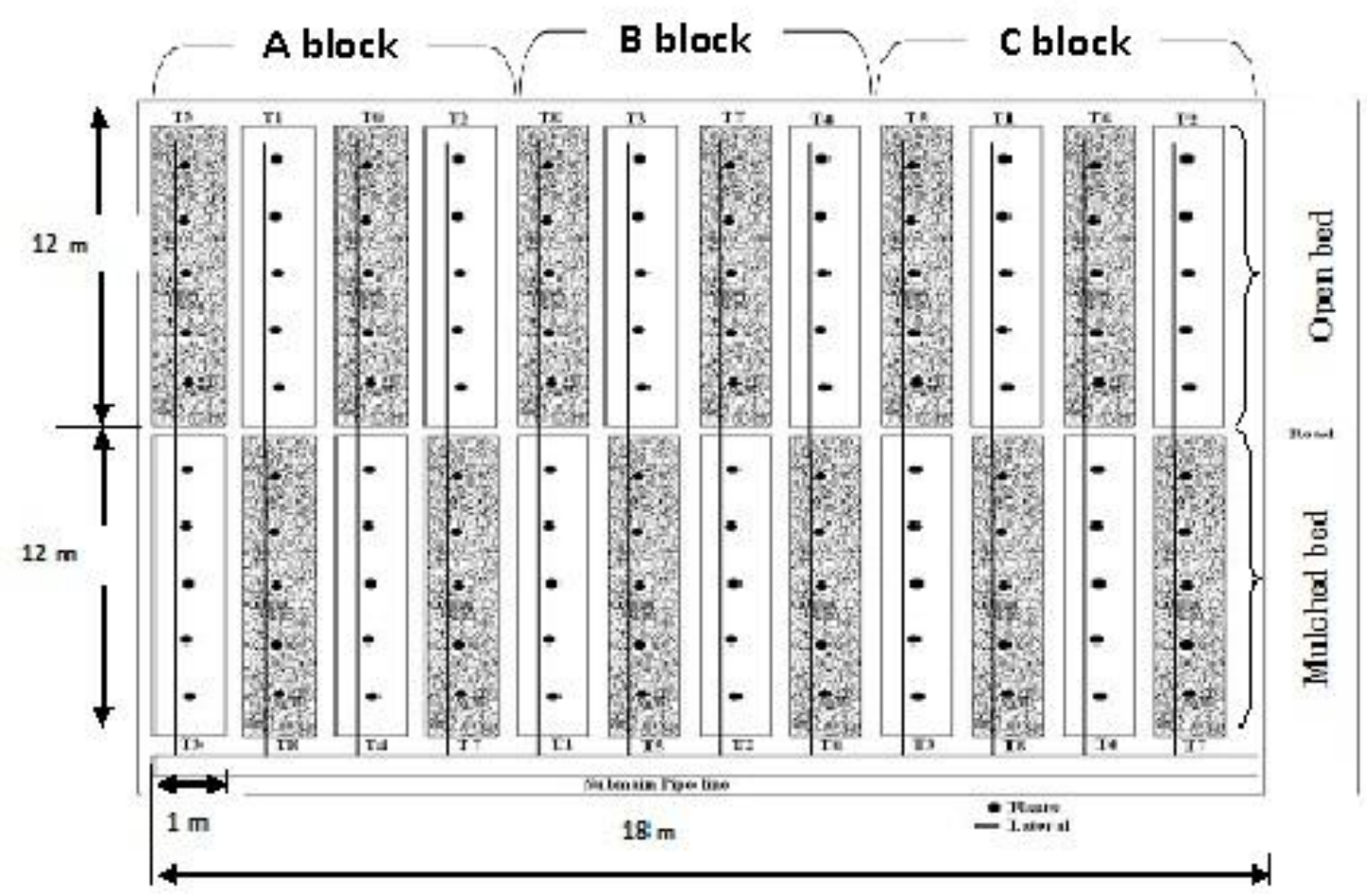

Figure 1a. Layout of banana experimental field
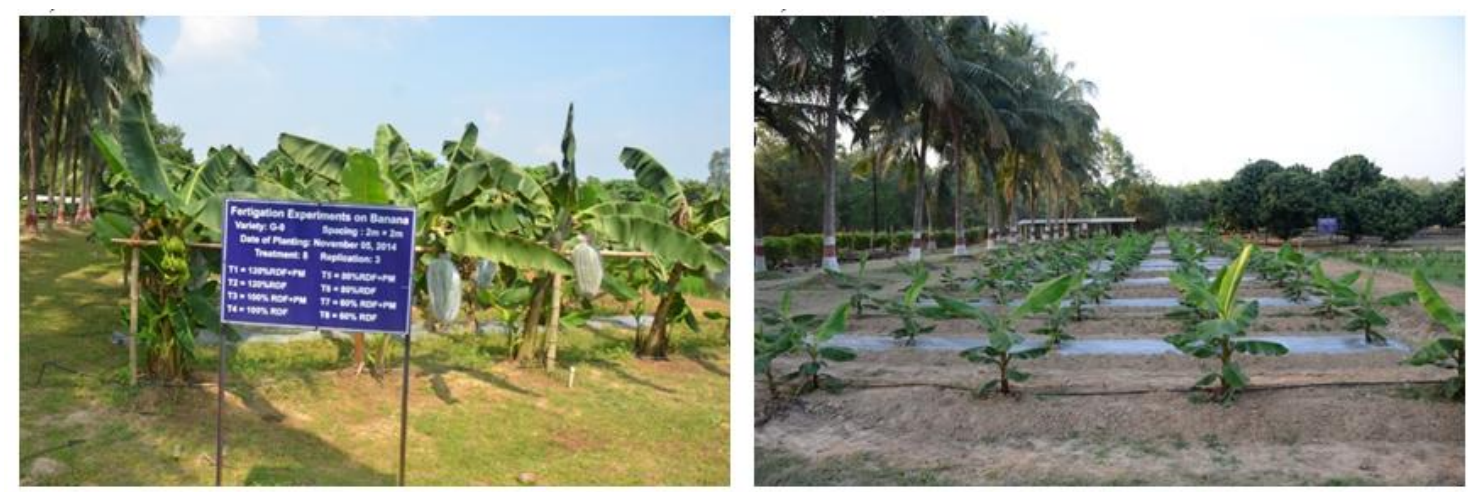

Figure 1b. Experimental layout of banana crop with micro irrigation and black plastic mulch at PFDC experimental field, IIT Kharagpur, India

\section{Estimation of crop water requirement and irrigation water supply}

Reference crop evapotranspiration $\left(\mathrm{ET}_{\mathrm{O}}\right)$ was estimated using the FAO-56 modified Penmanmethod using weather data collected from Weather Station, $0.5 \mathrm{~km}$ away from the field site. The values of crop coefficient (Kc) suggested by Allen et al. (1998) were considered and appropriately adjusted. Soil surface evaporation component in crop evapotranspiration is considered negligible as it was covered with the black plastic mulch. The actual evapotranspiration was estimated by multiplying reference evapotranspiration with crop coefficient for different months based on crop growth stages. The daily irrigation water requirement for the banana crop was estimated using the following relationship: 


$$
I R=E T_{0} \times K_{e}-R_{e}
$$

where:

IR Net depth of irrigation ( $\left.\mathrm{mm} \mathrm{day}^{-1}\right)$

$\mathrm{ET}_{\mathrm{o}}$ Reference evapotranspiration (mm day- ${ }^{1}$ )

$\mathrm{K}_{\mathrm{c}} \quad$ Crop coefficient

$\mathrm{R}_{\mathrm{e}} \quad$ Effective rainfall (mm day $\left.{ }^{-1}\right)$

The net volume of water required by the plant can be calculated by the relationship

where:

$$
V=I R \times A
$$

$\mathrm{V} \quad$ Net volume of water required by a plant $\left(\mathrm{L} \mathrm{day}^{-1}\right.$ plant $\left.^{-1}\right)$

A Area under each plant (i.e. spacing between rows, $\mathrm{m} x$ spacingbetween plants, $\mathrm{m}$ )

The reference evapotranspiration was estimated using FAO 56 method. The crop coefficient $\mathrm{K}_{\mathrm{c}}$ was estimated considering the local soil condition. The effective rainfall is the part of the rainfall that forms the part of the consumptiveuse. The irrigation water was supplied after subtracting the effective rainfall from the total irrigation requirement (Eq. 1).The water requirement was estimated for the main and ratoon crop of banana using Eq. 2. The irrigation water was applied for the entire crop season as per the crop growth stages using drip irrigation (Figure $2 a$ ).

a)

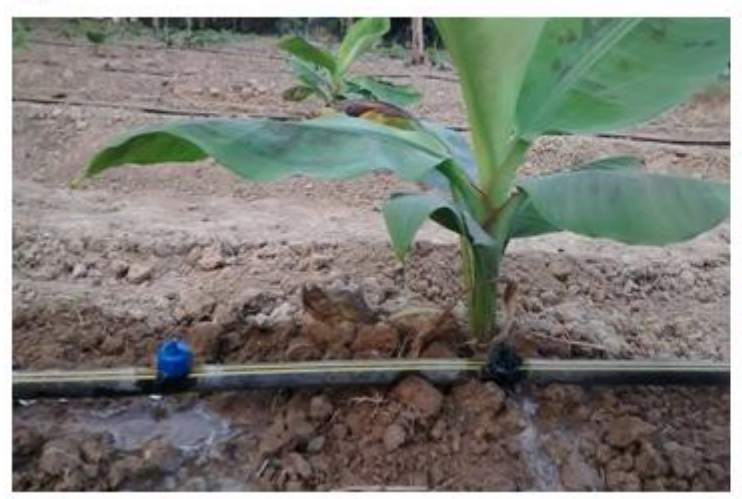

b)

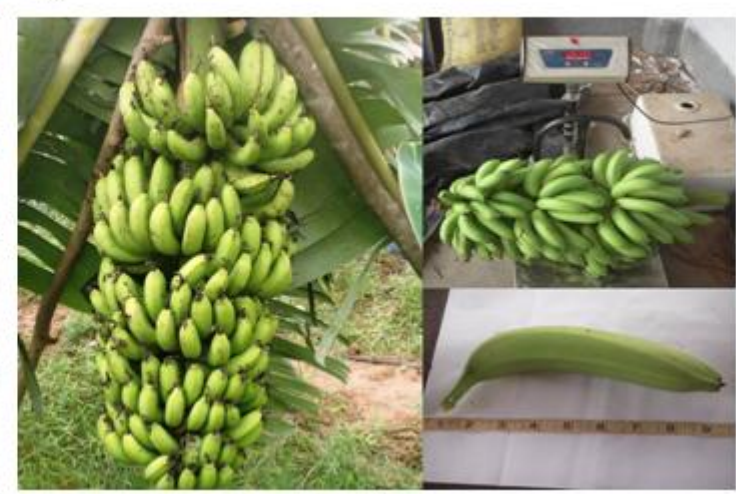

Figure 2a. Application of fertilizer for banana crop using micro irrigation Figure $2 \boldsymbol{b}$. Weighing banana bunch and measuring length of banana fruit

\section{Fertigation schedule application}

The dose of fertilizer for Grand Naine was considered as 200:60:300 N: $\mathrm{P}_{2} \mathrm{O}_{5}: \mathrm{K}_{2} \mathrm{O}$ $\mathrm{kgha}^{-1}$ as recommended by Mahalakshmi et al. (2001) and Nalina et al. (2000). This recommendation is for manual application. Using this recommended values weekly schedule was estimated considering the nutrients requirement at different growth stages of plant as given in Table 1. Water soluble fertilizers were applied twice in a week through drip irrigation system. 


\section{Monitoring the growth parameters}

Growth parameters monitoring under each treatment included seasonal increase in plant height $(5 \mathrm{~cm}$ from the base of thepsuedostem to the point of interaction of the petioles ofthe two youngest leaves), plant girth (5 cmabove the ground levels), the number of green leaves, and leaf area (Murray, 1960). Mature bunches were harvested when they reached full three quarter shape. Yield and yield components were recorded under each treatment (Figure $2 b$ ). The second hand of freshly harvested bunch was used to measure the fruit quality analysis (Pulp:peel ratio, TSS, Total sugar, Acidity) as suggested by Dadzie \& Orchard (1997).

Table 1. Fertilizer recommendation for banana crop

\begin{tabular}{c|c|c}
\hline $\begin{array}{c}\text { Crop stage } \\
\text { (No. of weeks after transplantation) }\end{array}$ & $\begin{array}{c}\text { Quantity (N:P:K), } \\
\text { g/plant }\end{array}$ & $\begin{array}{c}\text { Schedule ((N:P:K), } \\
\text { g/plant/fertigation* }\end{array}$ \\
\hline Basal Dose & $1 \mathrm{~kg} \mathrm{Neem} \mathrm{Cake,+20} \mathrm{FYM}$ & While Transplanting \\
\hline Initial stage (1 to 8) & $58: 30: 30$ & $3.6: 1.9: 1.9$ \\
\hline Developmental stage (9 to 16) & $90: 30: 90$ & 5.6: $1.9: 5.6$ \\
\hline Fruiting stage (17 to 24$)$ & $32: 00: 100$ & $2: 0: 6.3$ \\
\hline Harvesting stage (25 to 40) & $20: 00: 80$ & $0.7: 0: 2.7$ \\
\hline
\end{tabular}

*fertigation is scheduled twice in a week

\section{Monitoring the plant chemical parameters}

Third leaf laminas were sampled (after the first hand of male flowers could be seen onthe inflorescence) as recommended by Martin-Prével (1992); samples from bunch stalkand fruits were also taken and their nutrient concentrations were determined. The plant parts were dried at $80^{\circ} \mathrm{C}$ for 48 hours and the concentrations of $\mathrm{N}$ (Kjeldahl method), P (Spectro colorimeter) and $\mathrm{K}$ (flame photometer) were measured. The amountof nutrient in each organ was calculated from dry weight and nutrient concentration.

Statistical analysis was performed using SPSS software package to test the significance of different treatments individually as well as in combinations experimental ANOVA was performed by the method described by Gomez and Gomez (1984). In order to the comparisons between the treatment means and variance were tested at $5 \%$ significance level. Duncan multiple range test was conducted to know the significance level between the treatments and groups of treatments.

\section{Results and Discussion}

\section{Estimated water requirement for banana crop}

Reference crop evapotranspiration ( $\mathrm{ET}_{\mathrm{o}}$ ) was estimated using the FAO-56 modified Penman method using weather data. The actual evapotranspiration was estimated by multiplying reference evapotranspiration with crop coefficient based on crop growth stage. In present study the value for daily crop coefficient $(\mathrm{Kc})$ was estimated using dual crop coefficient method. Summation of both Kcb and Ke curve makes crop coefficient (Kc) curve on daily basis for banana crop. The soil evaporation coefficient $(\mathrm{Ke})$ was considered zero when soil is covered with plastic mulch. Therefore the value of Kcb is 
considered as Kc for calculation of crop evapotranspiration under mulch cover. The ground cover reduction factor for banana crop under drip irrigation started from 0.1 and maximum ground cover estimated is about 0.96 at the developmental stage. The daily irrigation water requirement for the banana crop was estimated by subtracting the effective rainfall from the calculated evapotranspiration. The estimated quantity of water applied to banana plants for main and ratoon crop was 1236, $612 \mathrm{~mm}$ for without mulch and $1115 \mathrm{~mm}, 520 \mathrm{~mm}$ for plastic mulch treatment respectively. Figure 3 shows the month wise distribution of banana crop water requirement for the tissue cultured banana plantlets transplanted in October month. The total crop duration was 11-12 months for main crop and 10-11 months for ratoon crop. The crop water requirement of banana varies from 1.59 to $19.6 \mathrm{~L} \mathrm{day}^{-1}$ plant $^{-1}$ from early stage to peak demand period without mulch and 0.66 to $17.71 \mathrm{~L} \mathrm{day}^{-1}$ plant $^{-1}$ for plastic mulch covered condition (Fig. 3). The total quantities of water applied to banana plants were $3.43 \mathrm{~m}^{3}$ through drip irrigation system without plastic mulch coverand to $2.59 \mathrm{~m}^{3}$ for drip with plastic mulch covered condition.

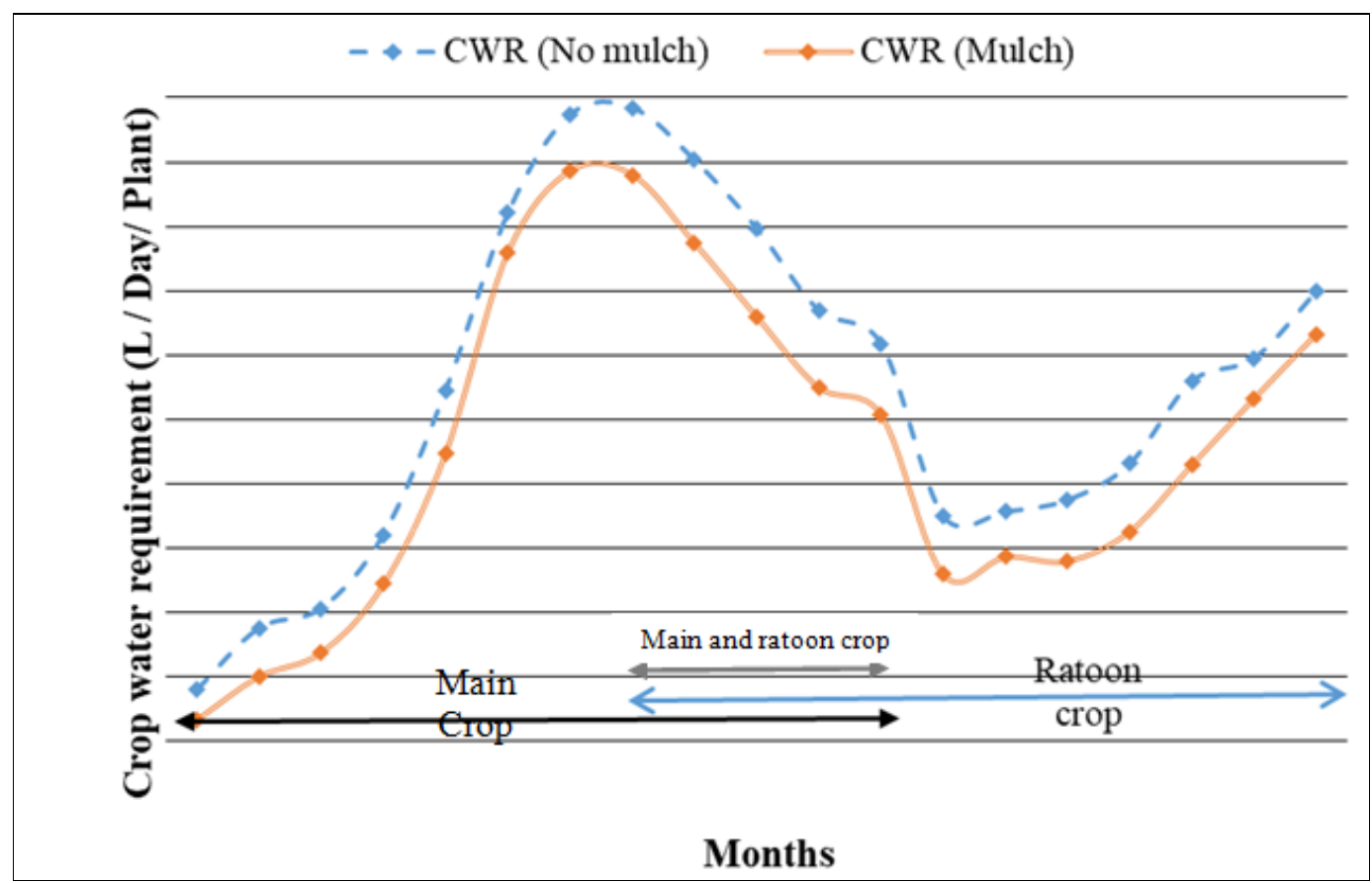

Figure 3. Estimated crop water requirement of banana in open and plastic mulch conditions

\section{Effect of fertigation levels on biometric properties of banana crop}

Treatment wise biometric observations of the crop were recorded and after analysis of data these are given in Table 2. Pooled data over two crop season indicates that vegetative growth parameters were significantly influenced by different level of fertigation treatments. Table 2. shows the values of biometric attributes (plant height, stem girth, no. of functional leaves and leaf area) under different treatments. The results showed that thetreatments differences were very highly significant forplant height, no. of functional leaves \& significant for leaf area of the main plant and ratoon crop of banana cv. Grand Nain. The best growth parameters were obtained at $80 \%$ of RDF covered with plastic mulch $\left(\mathrm{T}_{5}\right)$ followed by $100 \%$ RDF covered with plastic mulch $\left(\mathrm{T}_{3}\right)$. 
The result indicated that there was a significant difference among fertigation treatments in pseudo stem height and stem circumference or girth. The stem height in all the treatments showed steady increase throughout the growt hcycle of the first and ratoon banana plants. The treatment $\mathrm{T}_{5}$ recorded the maximum plant height (207.1\&183.8) in comparison to other treatments, which was statistically at par with treatment $\mathrm{T}_{3} 80 \%$ of recommended dose of NPK through drip irrigation and soil covered with plastic mulch, which registered a plant height of $(201.6 \& 178.3)$ in first and ratoon crop respectively. While the treatment $\mathrm{T}_{8}$ had the lowest stem height (171.0\&153.4) in first and ratoon crop respectively. Growth response of banana to NPK fertilization through drip irrigation (fertigation) indicated that the $\mathrm{T}_{5}(80 \% \mathrm{RDF}+$ mulch) treatment responded best performance in terms of growth in main crop under study. These results are almost similar with the data reported by Belalcazar and Espinosa (2000). Increased uptake of nutrients particularly nitrogen under fertigation system could be attributed to enlarge of stem height. The absorbed nitrogen ultimately might have been utilized by the plants in the formation of complex substances like protein and amino acids which in turn help to build up new tissues (Childers, 1966). These results are in accordance with the findings of Martinsson et al. (2006) who obtained maximum plant height in starw berry for optimum dose of fertilizer application through drip.

Table 2. Response of fertigation and plastic mulch on biometric properties of plants

\begin{tabular}{l|l|l|l|l|l|l|l|l}
\hline \multirow{2}{*}{ Treatment } & \multicolumn{2}{|c|}{$\begin{array}{c}\text { Pseudostem height at } \\
\text { shooting } \\
\text { (cm) }\end{array}$} & $\begin{array}{c}\text { Pseudostem girth } \\
\text { at shooting } \\
\text { (cm) }\end{array}$ & $\begin{array}{c}\text { Functional leaves } \\
\text { up shooting } \\
\text { (No) }\end{array}$ & \multicolumn{2}{c}{$\begin{array}{c}\text { Leaf area } \\
\left(\mathbf{m}^{2}\right)\end{array}$} \\
\cline { 2 - 10 } & $\begin{array}{c}\text { First } \\
\text { Crop }\end{array}$ & $\begin{array}{c}\text { Ratoon } \\
\text { Crop }\end{array}$ & $\begin{array}{c}\text { First } \\
\text { Crop }\end{array}$ & $\begin{array}{c}\text { Ratoon } \\
\text { Crop }\end{array}$ & $\begin{array}{c}\text { First } \\
\text { Crop }\end{array}$ & $\begin{array}{c}\text { Ratoon } \\
\text { Crop }\end{array}$ & $\begin{array}{c}\text { First } \\
\text { Crop }\end{array}$ & $\begin{array}{c}\text { Ratoon } \\
\text { Crop }\end{array}$ \\
\hline $\mathrm{T}_{1}$ & $187.0 \mathrm{~cd}$ & $157.0 \mathrm{~cd}$ & 55.9 & $44.5 \mathrm{c}$ & $11.3 \mathrm{~d}$ & $10.7 \mathrm{e}$ & $0.9 \mathrm{~cd}$ & $0.91 \mathrm{~cd}$ \\
\hline $\mathrm{T}_{2}$ & $176.0 \mathrm{de}$ & $156.0 \mathrm{~cd}$ & 54.9 & $43.5 \mathrm{c}$ & $10.3 \mathrm{de}$ & $10.3 \mathrm{e}$ & $0.9 \mathrm{~d}$ & $0.82 \mathrm{de}$ \\
\hline $\mathrm{T}_{3}$ & $201.6 \mathrm{ab}$ & $178.3 \mathrm{ab}$ & 57.0 & $48.7 \mathrm{~b}$ & $13.7 \mathrm{~b}$ & $12.7 \mathrm{~b}$ & $1.2 \mathrm{ab}$ & $1.08 \mathrm{ab}$ \\
\hline $\mathrm{T}_{4}$ & $189.1 \mathrm{bcd}$ & $164.6 \mathrm{~cd}$ & 56.5 & $46.5 \mathrm{bc}$ & $12.3 \mathrm{c}$ & $11.7 \mathrm{c}$ & $1.0 \mathrm{bc}$ & $0.94 \mathrm{c}$ \\
\hline $\mathrm{T}_{5}$ & $207.1 \mathrm{a}$ & $183.8 \mathrm{a}$ & 60.6 & $52.2 \mathrm{a}$ & $15.0 \mathrm{a}$ & $13.7 \mathrm{a}$ & $1.3 \mathrm{a}$ & $1.1 \mathrm{a}$ \\
\hline $\mathrm{T}_{6}$ & $193.3 \mathrm{bc}$ & $167.7 \mathrm{bc}$ & 58.5 & $46.8 \mathrm{bc}$ & $12.7 \mathrm{bc}$ & $12.0 \mathrm{bc}$ & $1.1 \mathrm{~b}$ & $1.05 \mathrm{~b}$ \\
\hline $\mathrm{T}_{7}$ & $181.1 \mathrm{cde}$ & $156.1 \mathrm{~cd}$ & 53.6 & $43.3 \mathrm{c}$ & $10.7 \mathrm{e}$ & $10.3 \mathrm{e}$ & $0.9 \mathrm{~cd}$ & $0.89 \mathrm{cde}$ \\
\hline $\mathrm{T}_{8}$ & $171.0 \mathrm{e}$ & $154.4 \mathrm{~d}$ & 53.8 & $43.2 \mathrm{c}$ & $10.0 \mathrm{e}$ & $10.0 \mathrm{e}$ & $0.8 \mathrm{~d}$ & $0.81 \mathrm{e}$ \\
\hline $\mathrm{Sem} \pm$ & 4.94 & 4.02 & $\mathrm{NS}$ & 1.17 & 0.31 & 0.29 & 0.04 & 0.03 \\
\hline
\end{tabular}

* Any two means having a common letter are not significantly different at the $5 \%$ level of significance

Pooled mean values of two crop season showed that fertigation with 80 per cent RDF through drip irrigation and plastic mulch $\left(\mathrm{T}_{5}\right)$ recorded highest stem girth $(60.6$ and 52.2 $\mathrm{cm})$ in main and ratoon crop respectively. It was followed by the treatment $\mathrm{T}_{3}(57 \&$ $48.7 \mathrm{~cm})$ and the lowest value was recorded in $\mathrm{T}_{8}(53.8 \& 43.2 \mathrm{~cm})$ in main and ratoon crop respectively. Effect of fertigation level on stem girth in main crop was not statistically significant. However, effect of treatment was significant in ratoon crop. This may be due to plastic mulch which influences the emergence and growth of suckers. Hegde and Srinivas (1991) also had similar observations as in the present study which indicated that increasein amount of nitrogenand potassium fertilization had no significant effect on stem girth effect. This is perhaps due to sufficient amounts of soil NPK $80 \%$ RDF maintained adequate vegetative growth in this study. 
A banana crop should produce sufficient number of leaves to harness thelight energy and synthesize adequate photosynthates for biomass production. The role of leaf parameters such as number of leaves produced and number of functional leaves retained at shooting is crucial in determining the yield potential.The fertilizer treatment had little effect in producing number of leaves. The leaf number increased slightly in response to the fertigation treatments. At the time of flowering, all the treatments produced the same number of leaves (ranged from 10-14 leaf/plant). This exceeded the lowest number of leaves (eight leaves) required at flowering to obtain high yield (Martinez, 1984). The application of $80 \%$ NPK per plant and plastic mulch $\left(\mathrm{T}_{5}\right)$ significantly enhanced the number of leaves at all stages of growth both in plant and ratoon crops which indicated that the application of NPK at optimum rate promoted faster rate of leaf production.

Apart from the number of leaves, leaf area at any growth stage is very critical for banana crop as it has a close bearing on photosynthetic efficiency reflecting on biomass production. An increase in leaf area results in better utilization of solar energy. For individual leaf, treatment $\mathrm{T}_{5}$ had the largest leaf area followed by $\mathrm{T}_{3}$ which is at par with treatment $\mathrm{T}_{5}$.

The increased height, girth, number of leaves and leaf area in mulched treatments corresponding with same fertigation level was recorded. This may be attributed to sufficient soil moisture near root zone and minimized leaching of nutrients due to mulching. Similar findings have also been obtained by Ansary and Roy (2005) in water melon, Al-Majali and Kasrawi (1995) in muskmelon, Hallidri (2001) in cucumber.

The maximum number of suckers were recorded in the treatment $\mathrm{T}_{3}(100 \% \mathrm{RDF}$ with plastic mulch) as 10.7 in the main crop and 4.3 in the ratoon crop. Treatment $\mathrm{T}_{5}(80 \%$ RDF covered with plastic mulch) took $336 \& 305.7$ days to harvest main and ratoon crop respectively which was lesser than other treatments (Table 3.). Crop duration or is an important factor to be considered in banana cultivation especially under fertigation through drip. The crop duration can be divided into two phases viz., days taken from planting to shooting in main crop or sucker setting to shooting of ratoon crop and days taken from shooting to harvest. In the present experiment, it was revealed that optimum dose of fertigation through drip with plastic mulch caused reduction in crop duration of main and ratoon (Table 3). From these experimental results, it appears that the main crop grown under treatment $\mathrm{T}_{5}$ shooting flower nine days earlierthan treatment $\mathrm{T}_{4}(100 \% \mathrm{RDF}$ with no mulch), while in the ratoon crop eight days early flower emerges from the treatment $T_{5}$ compare to the treatment $T_{4}$. The early shooting under the treatment $\left(T_{5}\right)$ could be attributed to the rapid production of leaves, which would have elaborated more photosynthates and increased flowering stimulus.

Normally, higher fertigation and irrigation levels cause excess vegetative growth that may delay in flowering period. The delay in shooting and harvest in the treatments $T_{1}$ and $\mathrm{T}_{2}$ may be due to increased nitrogen status which might have been causedby the supra optimal level of nutrients leading to poor development of root system which also reflected in lesser number of roots. When the root number is less, it may notbe adequate to meet the nutrients required by the aerial parts. This is in agreement with Nalina et al. (2000) whofound that the crop supplied with optimum dose of fertigation needs less number of days to shooting (226 days) and total crop duration (338 days). Mahalakshmi (2001) also noted early shooting, early bunch development including total crop duration under low levels of nutrients and water. This can be explained due to the better source sink relationship in treatment $T_{5}$ which recorded more leaf area with more photosynthetic activity, translocating the carbohydrate efficiently to the development of bunch. 
Santosh - Tiwari: Response of tissue cultured banana cv. Grand Naine to different levels of nutrients under drip fertigation and black plastic mulch

-1481 -

Table 3. Effect of fertigation \& plastic mulch treatments on number of suckers, days taken from flowering to harvest

\begin{tabular}{c|c|c|c|c|c|c}
\hline \multirow{2}{*}{ Treatment } & \multicolumn{2}{|c|}{$\begin{array}{c}\text { Suckers } \\
\text { (No) }\end{array}$} & \multicolumn{2}{c|}{$\begin{array}{c}\text { Days to flowering } \\
\text { (days) }\end{array}$} & \multicolumn{2}{c}{$\begin{array}{c}\text { Days to harvesting } \\
\text { (days) }\end{array}$} \\
\cline { 2 - 7 } & $\begin{array}{c}\text { First } \\
\text { Crop }\end{array}$ & $\begin{array}{c}\text { Ratoon } \\
\text { Crop }\end{array}$ & First Crop & Ratoon Crop & First Crop & Ratoon Crop \\
\hline $\mathrm{T}_{1}$ & $8.3 \mathrm{ab}$ & 2.7 & $269.7 \mathrm{~b}$ & $275.7 \mathrm{bc}$ & $358.7 \mathrm{c}$ & $335.3 \mathrm{~cd}$ \\
\hline $\mathrm{T}_{2}$ & $5.7 \mathrm{~d}$ & 3.3 & $281.3 \mathrm{c}$ & $281.3 \mathrm{c}$ & $374.0 \mathrm{de}$ & $350.7 \mathrm{e}$ \\
\hline $\mathrm{T}_{3}$ & $9.3 \mathrm{ab}$ & 4.0 & $258.0 \mathrm{a}$ & $263.3 \mathrm{ab}$ & $341.0 \mathrm{a}$ & $318.0 \mathrm{~b}$ \\
\hline $\mathrm{T}_{4}$ & $6.7 \mathrm{bc}$ & 3.7 & $266.0 \mathrm{ab}$ & $269.7 \mathrm{bc}$ & $356.7 \mathrm{c}$ & $331.7 \mathrm{~cd}$ \\
\hline $\mathrm{T}_{5}$ & $9.7 \mathrm{a}$ & 4.3 & $258.3 \mathrm{a}$ & $251.7 \mathrm{a}$ & $342.7 \mathrm{ab}$ & $305.7 \mathrm{a}$ \\
\hline $\mathrm{T}_{6}$ & $6.7 \mathrm{bc}$ & 4.0 & $261.0 \mathrm{ab}$ & $270.0 \mathrm{bc}$ & $354.0 \mathrm{bc}$ & $330.3 \mathrm{c}$ \\
\hline $\mathrm{T}_{7}$ & $8.0 \mathrm{c}$ & 3.3 & $280.0 \mathrm{c}$ & $276.7 \mathrm{c}$ & $371.0 \mathrm{~d}$ & $340.0 \mathrm{~d}$ \\
\hline $\mathrm{T}_{8}$ & $4.3 \mathrm{c}$ & 2.7 & $292.7 \mathrm{~d}$ & $278.7 \mathrm{c}$ & $386.0 \mathrm{e}$ & $356.3 \mathrm{e}$ \\
\hline $\mathrm{Sem} \pm$ & 0.44 & $0.26 \mathrm{NS}$ & 3.74 & 6.05 & 4.25 & 2.71 \\
\hline
\end{tabular}

* Any two means having a common letter are not significantly different at the $5 \%$ level of significance

Yield and yield component are the most important economic traits, which are very highly influenced by fertigation treatments. Yield in banana is a function of bunch weight and number of plants perhectare. In the present study, the most important economic trait, namely bunchweight was significantly influenced by the various fertilizer treatments (Table 4). The maximum yield and bunch weight was obtained $\mathrm{T}_{5}$. The number of hands andfingers per bunch with treatments $\mathrm{T}_{5}, \mathrm{~T}_{3}, \mathrm{~T}_{6}$ and $\mathrm{T}_{4}$ were significantly greater than others fertigation treatments of the first and ratoon crop (Table 4). The bunch weight decreased when level of $\mathrm{N}, \mathrm{P}$ and $\mathrm{K}$ fertilizer doses decreased $\mathrm{T}_{7}$ and $\mathrm{T}_{8}$ also increased doses at $\mathrm{T}_{1}, \mathrm{~T}_{2}, \mathrm{~T}_{3}$ and $\mathrm{T}_{4}$. The results also showed thathe higher dose of fertilizer application (as in $\mathrm{T}_{1} \& \mathrm{~T}_{2}$ ) mayresult in small bunch weight. This was also observed by Bolanos et al. (2003) where excessive potassium applications reduced banana yield.

The increase in yield (bunch weight) was attributed toincrease in the total fruit weight. Highest yield was recorded in treatment $T_{5}$ and yield of treatment $T_{3}$ is at par with the yield $\mathrm{T}_{5}$ treatment $\left(64.49 \& 50.07 \mathrm{t} \mathrm{ha}^{-1}\right)$ in both main and ratoon crop. Remaining treatments show significant difference in yield. Similar findings were observed by Srinivas (1999), while studying the effect of N, P and K fertilizers on banana cv. Basrai. Kohli et al. (1976) reported that the nitrogen application significantlyinfluenced the fruit yield in both the crops (plantcrop, first ratoon and second ratoon).

The banana yield with drip fertigation in the presence of black plastic mulch $\left(\mathrm{T}_{1}, \mathrm{~T}_{3}\right.$, $\left.\mathrm{T}_{5}, \mathrm{~T}_{7}\right)$ were significantly higher than that obtained without mulch $\left(\mathrm{T}_{2}, \mathrm{~T}_{4}, \mathrm{~T}_{6}, \mathrm{~T}_{8}\right)$ with respective same amount of fertilizer application. The results of the present study agreed with the finding of Igbal et al. (2009), Wang et al. (2009), and Parmar et al. (2013) who indicated that plants under polyethylene mulch produce larger fruit and have higher fruit yield per plant because of the better plant growth due to favorable hydro thermal regime of soil and complete weed free environment. Furthermore, they mentioned that the extended retention of moisture and availability of moisture also lead to a higher uptake of nutrient for proper growth and development of plants.

There was significant difference in yield with the treatment $T_{5}$ in comparison with the Treatment $\mathrm{T}_{2}(120 \% \mathrm{RDF}$ with plastic mulch). Though banana crop is known for an 
exhaustive crop amount of nutrients requiring crop at various stages of growth and development, perhaps availability of nutrientsbeyond its requirement might probably have cause its negative effect. This is also evident from the present study, where in, application of nutrients above 100 per cent did not correspondingly increased bunch weight in both plant and ratoon crops. Similar study by Bolanos et al. (2003) has shown that appropriate amount of addition of nutrients in the soil is important in obtaining higher total fruit weight.

Table 4. Yield \& yield attributing characteristics of banana under different doses of fertigation and plastic mulch treatments

\begin{tabular}{|c|c|c|c|c|c|c|c|c|c|c|}
\hline \multirow[t]{2}{*}{$\begin{array}{l}\text { Treat- } \\
\text { ments }\end{array}$} & \multicolumn{2}{|c|}{ Bunch weight (kg) } & \multicolumn{2}{|c|}{$\begin{array}{l}\text { No of hands } \\
\text { /bunch }\end{array}$} & \multicolumn{2}{|c|}{$\begin{array}{l}\text { Number of } \\
\text { fingers/ hand }\end{array}$} & \multicolumn{2}{|c|}{ Finger length $(\mathrm{cm})$} & \multicolumn{2}{|c|}{$\begin{array}{c}\text { Yield } \\
\left(t_{\text {h }} \mathbf{h}^{-1}\right)\end{array}$} \\
\hline & FC & RC & FC & RC & FC & RC & FC & $\mathbf{R C}$ & FC & RC \\
\hline $\mathrm{T} 1$ & $15.32 \mathrm{c}$ & $16.80 \mathrm{abc}$ & $8.00 \mathrm{cde}$ & $6.33 \mathrm{abc}$ & $18.00 \mathrm{cde}$ & 12.67 & $19.02 \mathrm{bc}$ & $11.87 \mathrm{bc}$ & $38.30 \mathrm{~d}$ & $40.67 \mathrm{bc}$ \\
\hline $\mathrm{T} 2$ & $13.95 \mathrm{~cd}$ & $15.60 \mathrm{c}$ & $7.00 \mathrm{e}$ & $5.33 \mathrm{c}$ & $16.33 \mathrm{e}$ & 11.33 & $17.92 \mathrm{c}$ & $11.47 \mathrm{c}$ & $35.12 \mathrm{~d}$ & $40.90 \mathrm{bc}$ \\
\hline $\mathrm{T} 3$ & $24.62 \mathrm{ab}$ & $19.60 \mathrm{ab}$ & $9.33 \mathrm{ab}$ & $7.33 \mathrm{ab}$ & $23.67 \mathrm{a}$ & 14.00 & $20.84 \mathrm{ab}$ & $14.37 \mathrm{ab}$ & $62.66 \mathrm{ab}$ & $47.50 \mathrm{ab}$ \\
\hline $\mathrm{T} 4$ & $20.70 \mathrm{~b}$ & $17.77 \mathrm{abc}$ & $8.33 \mathrm{bcd}$ & $6.67 \mathrm{abc}$ & $21.00 \mathrm{abc}$ & 12.67 & $19.40 \mathrm{abc}$ & $13.17 \mathrm{abc}$ & $50.26 \mathrm{c}$ & $42.13 \mathrm{bc}$ \\
\hline T5 & $25.43 \mathrm{a}$ & $20.20 \mathrm{a}$ & $9.67 \mathrm{a}$ & $7.67 \mathrm{a}$ & $22.00 \mathrm{ab}$ & 15.00 & $21.55 \mathrm{a}$ & $15.87 \mathrm{a}$ & $64.49 \mathrm{a}$ & $50.07 \mathrm{a}$ \\
\hline T6 & $21.69 \mathrm{ab}$ & $18.20 \mathrm{abc}$ & $8.67 \mathrm{abc}$ & $7.00 \mathrm{abc}$ & $20.00 \mathrm{bcd}$ & 12.33 & $19.46 \mathrm{abc}$ & $12.60 \mathrm{abc}$ & $54.28 \mathrm{bc}$ & $\begin{array}{c}45.80 \\
\text { abc }\end{array}$ \\
\hline $\mathrm{T} 7$ & $11.64 \mathrm{~cd}$ & $16.03 \mathrm{bc}$ & $7.33 \mathrm{de}$ & $5.67 \mathrm{bc}$ & $17.33 \mathrm{de}$ & 12.00 & $18.59 \mathrm{c}$ & $11.82 \mathrm{c}$ & $23.83 \mathrm{e}$ & $39.83 \mathrm{c}$ \\
\hline $\mathrm{T} 8$ & $10.04 \mathrm{~d}$ & $14.70 \mathrm{c}$ & $7.00 \mathrm{e}$ & $5.67 \mathrm{bc}$ & $16.00 \mathrm{e}$ & 11.33 & $17.24 \mathrm{c}$ & $11.50 \mathrm{c}$ & $21.47 \mathrm{e}$ & $38.57 \mathrm{c}$ \\
\hline $\operatorname{Sem} \pm$ & 1.34 & 1.14 & 0.31 & 0.51 & 1.01 & 0.78 & 0.67 & 0.58 & 2.97 & 2.22 \\
\hline CD & 4.08 & 3.46 & 0.96 & NS & 3.08 & NS & 2.06 & 1.74 & 9.03 & 6.73 \\
\hline
\end{tabular}

$* \mathrm{FC}=$ First crop $* * \mathrm{RC}=$ Ratoon Crop

++ Any two means having a common letter are not significantly different at the $5 \%$ level of significance

\section{Effect of fertigation levels on leaf and fruit nutrient concentration}

Leaf nutrient concentration in banana plant provides information on the nutrient status of the plant. In banana crop cultivation practices, especially with nutrient management the optimum leaf concentration of major nutrients provides proper growth and development of banana plant. Nutrient analysis of leaf is an important diagnostic tool to verify if the crop suffers due to nutrient deficits or inadequate in amount if thecrop health status is good. Nutritional status must be in optimal concentration especially at flower initiation stage to achieve good growth and yield the leaf analysis should be done at this stage.

The nutrient content in the leaf of the present investigation both in plant and ratoon crops revealed thatthe treatmentT5 recorded higher of N,P and Kcontents over theother treatments, which indicated that the critical level of NPK was maintained (Fig. 4). Based on an average $\mathrm{N}$ content, one would getthe impression that nitrogen nutrition of banana is well above the critical level of $2.6 \% \mathrm{~N}$ in treatments T3, T4, T5 \& T6 as proposed by Lahav and Turner (1983). Different researchers have proposed different 
critical levels of $\mathrm{N}$ (in the 3rdleaf of banana)which ranged from 1.81 to $4.0 \%$ and an average of $3.03 \%$ (Angeles et al., 1993). Detailed examination of the data, however, revealed that $\mathrm{N}$ content was less than $3.03 \%$ in all the treatments except treatment $\mathrm{T} 3$ and T5, below this critical value photosynthesis will be affected and results in lesser yield. Theleaf P content were analyzed and compared with the critical level of $0.2 \%$ as proposed by Lahav and Turner (1983). Based on this criterion, Phosphorous content is in optimum level $(>0.14 \%)$ in all the treatments. Potassium content of leaves shows optimum (4.0-5\%) as given by Lahav and Turner (1983) except in Treatment T7 \& T8. This signifies the need for additional application of $\mathrm{K}$ fertilizers for improving nutrition and high yield of banana. It is well established fact that $\mathrm{K}$ improves the quality of banana, in addition to its role in increasing banana production.

Removal of plant nutrients in the harvested banana fruit is one of the major considerations informulating fertilizer recommendations. Figure 5 shows the higher nutrient content accumulated in $80 \%$ RDF covered with plastic mulch $\left(\mathrm{T}_{5}\right)$ followed by $100 \%$ RDF covered with plastic mulch $\left(\mathrm{T}_{3}\right)$.

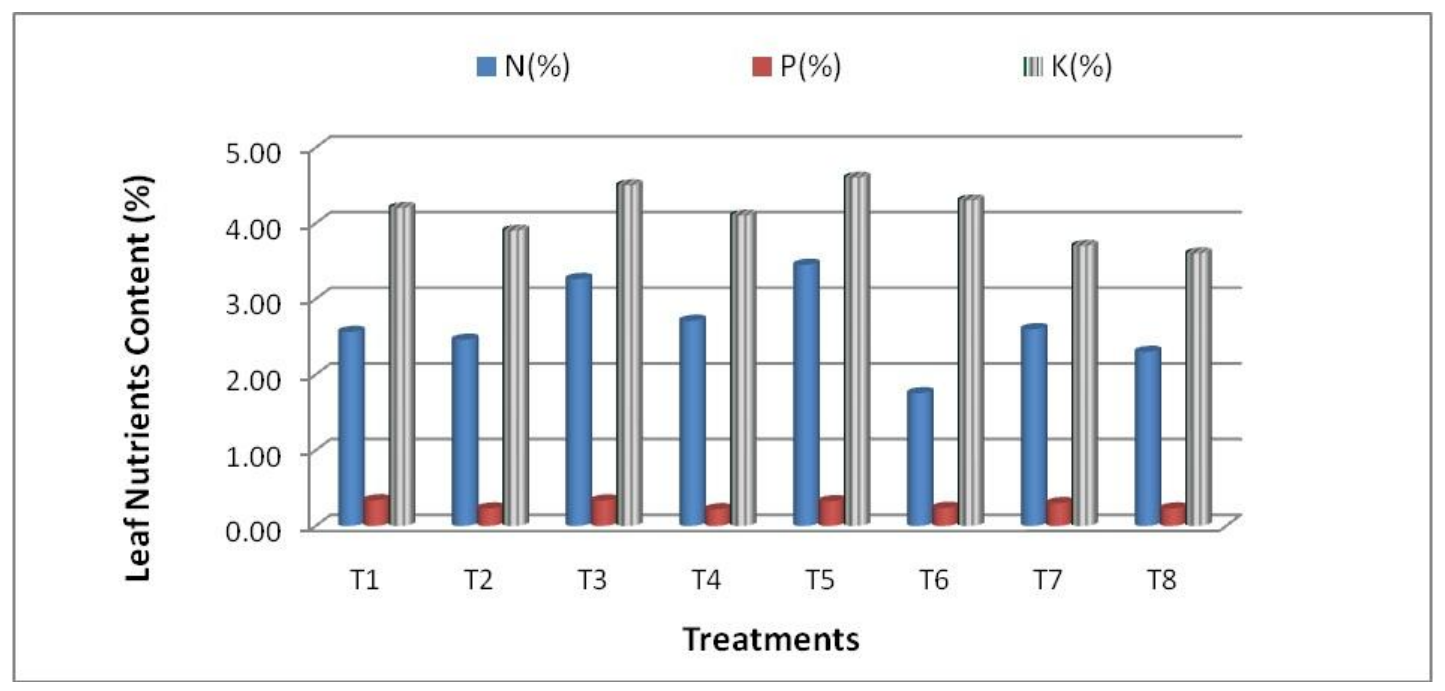

Figure 4. NPK content of banana leaf samples in different treatments

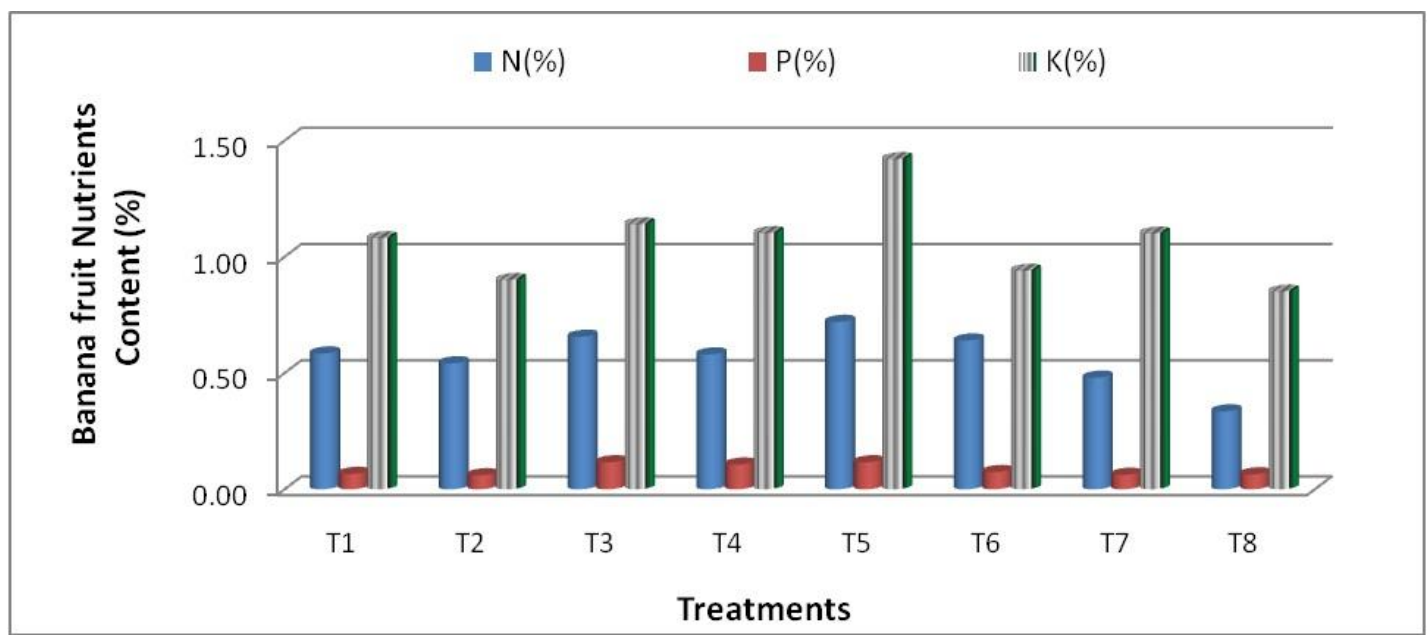

Figure 5. NPK content of banana fruit in different treatments 


\section{Effect of fertigation levels on qualitative parameters of banana}

In any production systems, the primary objective is to obtain maximum fruit yield per unit area without affecting the fruit quality. The fruit quality in banana is mainly judged by the sugar content and acidity in the pulp. A marked effect on fruit quality was observed with the application of adequate amount of nutrients. Higher levels of TSS, reducing and non-reducingbut a lower acidity were recorded in fruits in $\mathrm{T}_{5}$ or $\mathrm{T}_{3}$ (Table 5 ). Higher fruit quality especially sugar content can be explained due to the better role of nutrients particularly potassium which is involved in carbohydrate synthesis, breakdown and translocation of starch, synthesis of protein and neutralization ofphysiologically important organic acids. Further, the fruit quality parameters namely TSS and sugarswere significantly influenced by the fertigation treatments.

Table 5 shows that $\mathrm{T}_{5}$ recorded the highest pulp: peel ratio of 2.27:1 indicating thin skin. The minimum ratio was noticed in $\mathrm{T}_{8}$. Among the treatments evaluated, $\mathrm{T}_{5}$ was sweetest $\left(24.10{ }^{0}\right.$ Brix $)$ followed by $\mathrm{T}_{1}\left(23.4{ }^{0} \mathrm{Brix}\right)$ and $\mathrm{T}_{4}\left(23.3^{0} \mathrm{Brix}\right)$, banana fruit analysis revealed that the treatment $\mathrm{T}_{8}$ resulted in highest titrable acidity of $0.275 \%$. The study reveals that $\mathrm{N}$ content influences TSS, sugar and acidity of banana fruit (Nalina et al., 2000). Similarly Dinesh and Pandey (2008) recorded statistically significant values of TSS, total sugars and reducing sugars with application of $75 \%$ RDF. Hence the increased values of total sugars in banana might be due to higher uptake of nitrogen and potassium bythe plant.

Table 5. Effect of different fertigation treatments on fruit quality characteristics of banana crop

\begin{tabular}{|c|c|c|c|c|c|c|c|c|c|c|}
\hline \multirow[t]{2}{*}{$\begin{array}{l}\text { Treat- } \\
\text { ments }\end{array}$} & \multicolumn{2}{|c|}{$\begin{array}{l}\text { Pulp Peel } \\
\text { Ratio }\end{array}$} & \multicolumn{2}{|c|}{$\begin{array}{c}\text { TSS } \\
\left({ }^{\mathbf{0}} \mathrm{brix}\right)\end{array}$} & \multicolumn{2}{|c|}{$\begin{array}{c}\text { Reducing Sugar } \\
(\%)\end{array}$} & \multicolumn{2}{|c|}{$\begin{array}{l}\text { Non Reducing } \\
\text { Sugar }(\%)\end{array}$} & \multicolumn{2}{|c|}{$\begin{array}{c}\text { Acidity } \\
(\%)\end{array}$} \\
\hline & $\mathrm{FC}^{*}$ & $\mathrm{RC}^{* *}$ & $\mathrm{FC}$ & $\mathrm{RC}$ & $\mathrm{FC}$ & $\mathrm{RC}$ & $\mathrm{FC}$ & $\mathrm{RC}$ & $\mathrm{FC}$ & $\mathrm{RC}$ \\
\hline $\mathrm{T} 1$ & $1.9 \mathrm{bc}$ & $1.96 \mathrm{c}$ & $23.10 \mathrm{bc}$ & $22.18 \mathrm{a}$ & $13.00 \mathrm{bcd}$ & $12.48 \mathrm{a}$ & $\begin{array}{c}2.20 \\
b c\end{array}$ & $2.11 \mathrm{a}$ & 0.25 & 0.25 \\
\hline $\mathrm{T} 2$ & $1.9 \mathrm{bc}$ & $1.83 \mathrm{c}$ & $22.37 \mathrm{c}$ & $21.47 \mathrm{ab}$ & $12.73 \mathrm{~cd}$ & $12.22 \mathrm{ab}$ & $2.35 \mathrm{a}$ & $\begin{array}{c}2.26 \\
a b\end{array}$ & 0.26 & 0.30 \\
\hline $\mathrm{T} 3$ & $2.2 \mathrm{ab}$ & $2.47 \mathrm{a}$ & $23.77 \mathrm{ab}$ & $22.03 \mathrm{a}$ & $13.27 \mathrm{ab}$ & $12.47 \mathrm{a}$ & $1.84 \mathrm{e}$ & $1.73 \mathrm{a}$ & 0.25 & 0.27 \\
\hline $\mathrm{T} 4$ & $2.1 \mathrm{abc}$ & $\begin{array}{c}2.24 \\
\mathrm{ab}\end{array}$ & $23.20 \mathrm{bc}$ & $21.85 \mathrm{a}$ & $13.10 \mathrm{bcd}$ & $12.51 \mathrm{a}$ & $1.94 \mathrm{~d}$ & $1.86 \mathrm{a}$ & 0.25 & 0.25 \\
\hline T5 & $2.3 \mathrm{a}$ & $\begin{array}{c}2.41 \\
\mathrm{ab}\end{array}$ & $24.10 \mathrm{a}$ & $22.11 \mathrm{a}$ & $13.53 \mathrm{a}$ & $12.45 \mathrm{a}$ & $1.76 \mathrm{e}$ & $1.62 \mathrm{a}$ & 0.24 & 0.24 \\
\hline $\mathrm{T} 6$ & $2.1 \mathrm{abc}$ & $2.20 \mathrm{~b}$ & $23.43 \mathrm{ab}$ & $21.56 \mathrm{ab}$ & $13.13 \mathrm{abc}$ & $12.08 \mathrm{ab}$ & $2.12 \mathrm{c}$ & $1.87 \mathrm{ab}$ & 0.25 & 0.24 \\
\hline $\mathrm{T} 7$ & $1.9 \mathrm{c}$ & $1.86 \mathrm{c}$ & $22.77 \mathrm{bc}$ & $21.33 \mathrm{ab}$ & $12.77 \mathrm{bcd}$ & $11.96 \mathrm{~b}$ & $2.30 \mathrm{ab}$ & $2.15 \mathrm{~b}$ & 0.29 & 0.29 \\
\hline $\mathrm{T} 8$ & $1.8 \mathrm{c}$ & $1.78 \mathrm{c}$ & $22.37 \mathrm{c}$ & $20.95 \mathrm{~b}$ & $12.57 \mathrm{~d}$ & $11.77 \mathrm{~b}$ & $2.40 \mathrm{a}$ & $2.28 \mathrm{~b}$ & 0.27 & 0.27 \\
\hline $\operatorname{Sem} \pm$ & 0.93 & 0.07 & 0.27 & 0.26 & 0.15 & 0.14 & 0.03 & 0.04 & 0.01 & 0.02 \\
\hline $\begin{array}{c}\mathrm{CD} \\
(0.05)\end{array}$ & 0.28 & 0.24 & 0.80 & 0.78 & 0.45 & 0.42 & 0.11 & 0.13 & NS & NS \\
\hline
\end{tabular}

$* \mathrm{FC}=$ First crop $* * \mathrm{RC}=$ Ratoon Crop

++ Any two means having a common letter are not significantly different at the $5 \%$ level of significance

\section{Nutrient conversion efficiency}

Drip fertigation levels had shown profound influence on nutrients use efficiency in the banana crop cultivation (Table 6). The maximum Nitrogen conversion efficiency of 
$61.22 \mathrm{t} \mathrm{kg}^{-1}$ (ton of fruit yield to per $\mathrm{kg}$ of applied nitrogen), Phosphorous conversion efficiency of $537.42 \mathrm{t} \mathrm{kg}^{-1}$, Potassium conversion efficiency of $107.48 \mathrm{t} \mathrm{kg}^{-1}$ and total nutrient efficiency of $57.58 \mathrm{t} \mathrm{kg}^{-1}$ were registered under water soluble fertigation through drip fertigationat $80 \%$ NPK dose with plastic mulch cover treatment $\left(\mathrm{T}_{5}\right)$ and followed by water solublefertilizers application through drip at $100 \%$ NPK dose under plastic mulch cover $\left(\mathrm{T}_{3}\right)$. The increased nutrient conversion efficiency recorded under treatment $\mathrm{T}_{5}$ was mainly due to better crop growth and increased yield by effectiveutilization of available nutrients that were supplied at optimum level throughout the cropperiod to meet the crop demand (Bangar and Chaudhari, 2004).

Table 6. Nutrients conversion efficiency

\begin{tabular}{|c|c|c|c|c|}
\hline Treatment & $\begin{array}{c}\text { Nitrogen } \\
\text { use efficiency } \\
\left(\mathbf{t ~ k g}^{-1}\right)\end{array}$ & $\begin{array}{c}\text { Phosphorous use } \\
\text { efficiency } \\
\left(\mathbf{t ~ k g}^{-1}\right)\end{array}$ & $\begin{array}{c}\text { Potassium } \\
\text { use efficiency } \\
\left(\mathbf{t ~ k g}^{-1}\right)\end{array}$ & $\begin{array}{c}\text { Nutrient } \\
\text { use efficiency } \\
\left(\mathbf{t ~ k g}^{-1}\right)\end{array}$ \\
\hline $\mathrm{T}_{1}$ & 63.84 & 212.80 & 42.56 & 22.80 \\
\hline $\mathrm{T}_{2}$ & 58.54 & 195.13 & 39.03 & 20.91 \\
\hline $\mathrm{T}_{3}$ & 125.32 & 417.72 & 83.54 & 44.76 \\
\hline $\mathrm{T}_{4}$ & 100.53 & 335.09 & 67.02 & 35.90 \\
\hline $\mathrm{T}_{5}$ & 161.22 & 537.42 & 107.48 & 57.58 \\
\hline $\mathrm{T}_{6}$ & 135.70 & 452.32 & 90.46 & 48.46 \\
\hline $\mathrm{T}_{7}$ & 79.44 & 264.81 & 52.96 & 28.37 \\
\hline $\mathrm{T}_{8}$ & 35.79 & 238.57 & 47.71 & 25.56 \\
\hline Sem \pm & 6.23 & 21.14 & 4.22 & 2.26 \\
\hline $\mathrm{CD}(0.05)$ & 19.27 & 64.13 & 12.82 & 6.87 \\
\hline
\end{tabular}

\section{Economic analysis}

The gross cost of production, net return and benefit cost ratio for different fertigation levels are presented in Table 7 . The net returns were computed by multiplying average market rate of banana during the crop harvesting period with the yield obtained and subtracting the gross cost incurred in crop cultivation for different treatments. Maximum net profit of US \$. 7199.22 per hectare and B:C ratio of 5.2 were obtained for the treatment $T_{5}$ whereas the treatment $T_{8}$ resulted in lowest net profit of US $\$ 3277.77$ with $\mathrm{B}: \mathrm{C}$ ratio of 2.7. Increase in fertigation levels causes increase in the cost of production significantly due to high cost of water soluble fertilizers as the water soluble fertilizers are generally imported in India and sold at high prices compared to straight fertilizers. Higher amount of water soluble fertilizer application in treatments $T_{1}$ and $T_{2}$ and less yield obtained compared to other treatments $\left(\mathrm{T}_{5}, \mathrm{~T}_{3}, \mathrm{~T}_{6}\right.$ and $\left.\mathrm{T}_{4}\right)$ were the reason for least $\mathrm{B}: \mathrm{C}$ ratio in treatments $\mathrm{T}_{1}$ and $\mathrm{T}_{2}$. The fertilizer levels also had significant effect on B-C ratio. The results obtained for different fertigation levels in Table 7 are in similar trends with results reported by (Rajaraman and Pugalendhi, 2013). The mulched treatments $\mathrm{T}_{1}, \mathrm{~T}_{3}, \mathrm{~T}_{5} \& \mathrm{~T}_{7}$ resulted in greater net return per ha ranging between $4 \%$ and $23 \%$ and higher $\mathrm{B}: \mathrm{C}$ ratio than their corresponding treatments without mulch with drip fertigation. 
Table 7. Cost economic of banana crop with drip irrigation and plastic mulch for different treatments

\begin{tabular}{|c|c|c|c|c|}
\hline Treatments & $\begin{array}{l}\text { Gross cost of } \\
\text { production, } \\
\left(\text { US \$. ha } \mathbf{h}^{-1}\right)\end{array}$ & $\begin{array}{c}\text { Yield (first \& } \\
\text { ratoon crop) } \\
\left(\mathbf{t ~ h a}^{-1}\right)\end{array}$ & $\begin{array}{l}\text { Net return } \\
(\text { US \$. ha }\end{array}$ & B:C ratio \\
\hline $\mathrm{T}_{1}$ & 1658.35 & 78.97 & 4261.44 & 2.6 \\
\hline $\mathrm{T}_{2}$ & 1627.78 & 76.02 & 4070.87 & 2.5 \\
\hline $\mathrm{T}_{3}$ & 1523.42 & 110.16 & 6734.45 & 4.4 \\
\hline $\mathrm{T}_{4}$ & 1492.85 & 92.39 & 5432.94 & 3.6 \\
\hline $\mathrm{T}_{5}$ & 1388.49 & 114.56 & 7199.22 & 5.2 \\
\hline $\mathrm{T}_{6}$ & 1357.92 & 100.08 & 6144.33 & 4.5 \\
\hline $\mathrm{T}_{7}$ & 1253.55 & 63.66 & 3518.56 & 2.8 \\
\hline $\mathrm{T}_{8}$ & 1222.98 & 60.04 & 3277.77 & 2.7 \\
\hline $\mathrm{CD}(0.05)$ & & 8.42 & & 0.6 \\
\hline
\end{tabular}

\section{Conclusions}

At the current fertilizer input and farm gate banana prices, fertilizers can probably only be recommended to farmers when coupled with practices that increase soil moisture availability, such as micro irrigation and plastic mulch. Results of the present study showed that both main and ratoon crops, 80 per cent of the recommended fertigation dose (160 N: $48 \mathrm{P}: 240 \mathrm{~kg}_{\text {plant }}{ }^{-1}$ year $\left.{ }^{-1}\right)$ covered with plastic mulch $\left(\mathrm{T}_{5}\right)$ performed well in respect of growth parameters; maximum plant height, stem girth, functional leaves, yield parameters and shortened the total crop duration. Higher levels of TSS (24.1 ${ }^{0}$ brix), reducing (13.53\%) and non-reducing sugar (1.76\%), pulp: peel ratio $(2.34: 1)$ but a lower acidity $(0.25 \%)$ were recorded in fruits in treatment $\mathrm{T}_{5}$. The highest nutrient conversion efficiency $(57.58 \mathrm{t} / \mathrm{kg}$ nutrient) was obtained with treatment $\mathrm{T}_{5}$ and the lowest was $\left(20.91 \mathrm{t} / \mathrm{kg}\right.$ nutrient) with $120 \% \mathrm{RDF}$ without mulch cover $\left(\mathrm{T}_{2}\right)$. Hence, fertigation with 80 per cent of the recommended dose with plastic mulch was found to be optimum and economical.

Fertigation schedule comprises of optimum dose of nutrients and suitable frequency of nutrient applications. The present study determined the optimum dose of nutrients for banana crop in sandy loam soils and nutrient conversion efficiency under fertigation and plastic mulch. More research will be needed to know the suitable frequency of nutrients application based on climatic conditions and phenological stages of the crop. Comprehensive study required for better understanding of the effect of types of fertilizers, soil physical properties, soil chemical properties and moisture stress onnutrient uptake by banana plants, its yield and physical and chemical properties of banana fruits.

Acknowledgement. Authors are thankful to the National Committee on Plasticulture Applications in Agriculture \& Horticulture (NCPAH), Ministry of Agriculture, Govt. of India for providing necessary funds to conduct this field research experiment. Authors are also thankful to IIT Kharagpur for providing the necessary research facilities. 


\section{REFERENCES}

[1] Allen, R. G., Pereira, L. S., Raes, D., Smith, M. (1998): Crop evapotranspiration. Guidelines for computing crop water requirements. - Irrigation and Drainage Paper 56, Food and Agric. Organization of the United Nations, Rome, Italy, 300.

[2] Al-Majali, M. A., Kasrawi, M. A. (1995): Plastic mulch use and Method of planting influences on rainfed muskmelon production. - Pure and Applied Sci. 22(4):1039-1054.

[3] Angeles, D. E., Sumner, M. E., Lahav, E. (1993): Preliminary DRIS norms for banana. J. Plant Nutr. 16: 1059-1070.

[4] Ansary, S. H., Roy, D. C. (2005): Effect of irrigation and mulching on Growth, yield and quality of watermelon (Citrullus lanatus Thunb.). - Environment and Ecology 23(1): 141-143.

[5] Bangar, A. R., Chaudhary, B. C. (2004): Nutrient mobility in soil, uptake, quality and yield of Suru sugarcane as influenced by drip fertigation in medium vertisols. - J. Indian Soc. Soil Sci. 52 (2).

[6] Belalcazar, S., Espinosa, J. (2000): Effect of plant density and nutrient management on plantain yield. - Better crops international 14(1): 12-15.

[7] Bolanos, M. B., Morates, H.O., Celisal, D. (2003): Fertilizer (organic and inorganic) and production of 'Dominicoharton'. - Infomusa 12: 38-41.

[8] Call, R. E., Courter, J. W. (1989): Response of bell pepper to raised beds, black plastic mulch, spun bonded row cover and tickle irrigation. - Proceedings of $21^{\text {st }}$ NAPC.140146.

[9] Childers, N. F. (1966): Fruit Nutrition. - Horticulture Publication, New Brunswick, New Jersey, USA.

[10] Dadzie, B. K., Orchard, J. E. (1997): Routine post harvest screening of banana /Plantain Hybrids: Criteria and Methods. - Technical Guidelines 2. International Plant Genetic Resources Institute, Rome, Italy.

[11] Dinesh, K., Pandey, V. (2008): Relationship of pseudostem cross-sectional area with bunch weight, fruit quality and nutrient status in banana cv. Rasthali (PathkapooraAAB). - Indian J. Hort. 67:26-29.

[12] Gomez, K. A., Gomez, A. A. (1984): Statistical Procedures for Agricultural Research. John Wiley and Sons. New York. 91-115.

[13] Greenough, D. R., Black, L. L., Bond, W. P. (1990): Aluminum surface mulch : An approach to the control of tomato spotted with virus in solanaceous crops. - Plant Dis. 74: 805-808.

[14] Hallidri, M. (2001): Comparison of the different mulching materials on the growth, yield and quality of cucumber (Cucumis sativus L.). - Acta Hort. 559: 49-54.

[15] Hegde, D. M., Srinivas, K. (1991): Growth, yield, nutrient uptake and water use of banana crops under drip and basin irrigation with $\mathrm{N}$ and $\mathrm{K}$ ferilization. - Tropical Agriculture 68:331-334.

[16] Igbal, Q., Amjad, M., Rafique, A., Asif, A., Ahmad, R. (2009): Vegetative and reproductive evaluation of hot peppers under different plastic mulches in poly/plastic tunnel. - Pak. J. Agric. Sci. 46: 113-118.

[17] Kohli, R. R., Chacko, E. K., Randhawa, G. S. (1976): Effect of spacing and nutritional levels on growth and fruit yield of Robusta banana. - Indian J. Agric. Sci. 46 (8): 382385.

[18] Lahav, E. (1995): Banana nutrition. - In: Gowen, S. (ed.) Bananas and plantains. Chapman \& Hall, London, 258-316.

[19] Lahav, E., Turner, D. (1983): Banana nutrition, Berne. Bull No. 7. - International Potash Institute, Horgen, Switzerland.

[20] Mahalakshmi, M., Kumar, N., Jayakumar, P., Soorianathasundara, K. (2001): Fertigation study in banana under high density planting system. - South Indian J. Hort. 49 (Special): 86-91. 
[21] Martinez, A. (1984): Effect of sucker removal on plantain yields in the humid tropics of Colombia. - Rev. Ins. Colomb. Agripecuario 19: 357-359.

[22] Martin-Prevel, P. (1992): Banana. - In: Wichman, W. (ed) IFA, World fertilizer manual. International fertilizer industry association, Paris. 398-409.

[23] Martinsson, M., Kwast, A., Cieslinski, G., Treder, W. (2006): Impact of production systems and fertilizer application on yield and quality of strawberries. - Acta Horticulturae 708: 59-64.

[24] Murray, D. B. (1960): The effect of deficiencies of the major nutrients on growth and leaf analysis of the banana. - Trop. Agric. Trin. 37: 97-106.

[25] Nalina, L., Kumar, N., Sathiamoorthy, S. (2000): Studies on high density planting in banana cv. Robusta (AAA). - Indian J. Hort. 57(3): 190-195.

[26] Pandey, S. D., Jayabhaskaran, K. J., Laxman, R. H., Shanti, V. P. and Mustaffa, M. M. (2001): Effect of irrigation, $\mathrm{N}$ fertigation and planting geometry on growth and yield of banana cv. Nendran. - South Indian Horticulture 49:76-79.

[27] Parmar, H. N., Polara, N. D., Viradiya, R. R. (2013): Effect of mulching material on growth, yield and Quality of watermelon (Citrullus lanatus thunb) Cv. Kiran. Univ. - J. Agric. Res. 1: 30-37.

[28] Rajaraman, G., Pugalendhi, L. (2013): Potential impact of spacing and fertilizer levels on the flowering, productivity and economic viability of hybrid bhendi (Abelmoschus esculentus L. Moench) under drip fertigation system. - American Journal Plant Sciences 4: $48-54$

[29] Srinivas, K. (1997): Growth, yield, and quality of banana in relation to N fertigation. Tropical Agriculture 74: 260-264.

[30] Sweeney, D. W., Graetz, D. A., Bottcher, A. B., Locascio, S. J., Campbell, K.L. (1987): Tomato yield and nitrogen recovery as influenced by irrigation method, nitrogen, sources and mulches. - Horti. Sci. 22(1): 27-29

[31] Tiwari, K. N., Mal, P. K., Singh, R. M., Chattopadhya, A. (1998a): Response of Okra to drip irrigation under mulch and non-mulch conditions. - Agricultural Water Management 38: $91-102$.

[32] Tiwari, K. N., Mukesh Kumar, Santosh, D. T., Vikash Kumar Singh, Maji, M. K., Karan, A. K. (2014): Influence of Drip Irrigation and Plastic Mulch on Yield of Sapota (Achraszapota) and Soil Nutrients. - Irrigation \& Drainage Systems Engineering 3(1):1-8.

[33] Tiwari, K. N., Singh, R. M., Mal, P. K., Chattopadhya, A. (1998b): Feasibility of drip irrigation under different soil covers in tomato. - Journal of Agricultural Engineering ISAE 35(2): 41-49.

[34] Wang, Z., Wang, C., Zhu, Y., Wang, Y. (2009): Influence of nitrogen fertilizer application rate on winter wheat (Triticum aestivum L.) flour quality and Chinese noodle quality. - Journal of the Science of Food and Agriculture 89: 1213-1220. 